\title{
Transport policy in Belgium: translating sustainability discourses into unsustainable outcomes
}

Kobe Boussauw $^{1}$ and Thomas Vanoutrive ${ }^{2}$

${ }^{1}$ Cosmopolis Centre for Urban Research - Department of Geography

Vrije Universiteit Brussel

Pleinlaan 2 room F4.55, B-1050 Brussels, Belgium

email: kobe.boussauw@vub.ac.be

tel. +3226293511

${ }^{2}$ Department of Transport and Regional Economics, Urban Studies Institute and Research Group for Urban Development

University of Antwerp

Prinsstraat 13, B-2000 Antwerpen, Belgium

email: thomas.vanoutrive@uantwerpen.be

tel. +3232654085 


\title{
Transport policy in Belgium: translating sustainability discourses into unsustainable outcomes
}

\begin{abstract}
In this paper, we challenge the so-called orthodox sustainable transport vision, by confronting it with two possibly troublesome issues; (1) the urge for growth, and (2) the question of social justice. On the basis of seven cases from Belgium, a country with a strong commuting culture and a traditional tendency towards multimodality, we show that the conversion of a sustainability discourse into policy actions often leads to realizations which are essentially to be labelled as non-sustainable. On the one hand we discuss a number of cases where additional travel is unintentionally stimulated, with an unforeseen contribution to global warming as a result. On the other hand, we refer to cases where subsidies for sustainable transport modes seem to be geared towards wealthier groups, while poorer groups are exposed to additional expenses. The cases cover different steps of the policy process: (1) problem definition and selection of indicators, (2) the choice of a particular solution, and (3) the design of the chosen plan or programme, and illustrate the mechanisms underlying goaldisplacements.
\end{abstract}

\section{Keywords}

sustainable transport; limits to growth; social justice; Belgium; transport policy 


\section{Introduction}

Although the societal impact of transport was debated before 1987, it is fair to state that the rise of sustainability thinking boosted by the Brundtland report has resulted in a new phase of thinking on transport policy. Indeed, the confrontation of the concept of sustainable development with local and regional transport policies in the global north has resulted in the emergence of a policy discourse on sustainable transport, also known as sustainable mobility ${ }^{1}$ (Baeten, 2000; Banister, 2008). According to Banister (2008) four transition lines are essential to sustainable mobility: travel mode choice, urban and regional planning, technology, and travel substitution. Together, these ideas and story-lines about cleaner cars, compact cities, and a modal shift to more sustainable modes of transport form the sustainable transport discourse.

The premise of discourse analysis is that such discourses have an impact on which and how problems are perceived, on the set of acceptable solutions, and because of this, on policy outcomes (Hajer, 1995; Low \& Gleeson, 2001; Low, 2005). Although the link between policy rhetoric and actual outcomes is seldom a direct one, it is reasonable to assume that a quarter of a century of sustainable mobility buzz has made transport policy 'greener' and more sustainable. However, as will be illustrated by the cases presented in this paper, sustainable transport rhetoric was also used to legitimate policies with questionable outcomes. The aim of the present paper is to better understand how the popular discourse of sustainable transport has been used to legitimate 'unsustainable' outcomes. To this end, seven cases of questionable 'sustainable mobility' policy acts are presented.

Before we turn to the specific cases, we provide an optimistic reading of sustainable mobility policy - a number of positive evolutions can indeed be observed - which is followed by a critical reflection. The latter offers the basis for our analysis of a selection of policy initiatives in Belgium. In this analysis, we explain how 'sustainable' aims and objectives translate into 'unsustainable' outcomes, and relevant mechanisms at work include a narrow selection of indicators, the conflation of relative and absolute figures, and a restricted focus on the characteristics of transport modes. These and other findings form the basis for a discussion of the meaning of the concept of 'sustainability', which will be wrapped up in the concluding section.

\footnotetext{
${ }^{1}$ In this paper, we largely stick to the term 'sustainable transport' instead of 'sustainable mobility', in order to avoid confusion with the broader sociological concept of 'mobilities' as introduced by Sheller and Urry (2006).
} 


\subsection{Reasons to be optimistic about sustainable transport}

Today, policy answers to the sustainable transport question are generally communicated through optimistic and encouraging figures. In Belgium, the focus of this paper, official indicators suggest that sustainability objectives are slowly but surely achieved within the field of transport. With an average annual growth of $2.41 \%$ between 2000 and 2011, inland navigation in the Flemish region could make a nice report (Meersman et al., 2013, p. 27). In 2011, sulphur emissions from inland shipping, rail and road transport have practically disappeared, but twenty, or even only ten years ago, the situation was entirely different (ibid., p. 90). When looking at Belgium's federal home-to-work travel survey, we see that both public transport and the bicycle have gained market share between 2005 and 2011 (Verhetsel et al., 2014, p.37). Also, national road traffic statistics show that the number of kilometres driven per car registered in Belgium is decreasing, while the number of train passengers increased by as much as 50\% between 2001 and 2010 (Statistics Belgium, 2014). Still in Belgium, we see the $\mathrm{CO}_{2}$ emissions of newly sold cars falling from $160 \mathrm{~g} / \mathrm{km}$ in 2002 to 130 $\mathrm{g} / \mathrm{km}$ in 2012 (MIRA, 2013).

And these are just some figures. Sustainable transport has become a common notion in many policy plans at almost all levels of government (Bulkeley and Betsill, 2005). At the European level, for example, the term is used to indicate a decoupling between the growth rate of transport and its associated adverse effects (Tight et al., 2004). At national or regional level, under the same heading, new technology is subsidized and efficiency increasing measures are funded. And at the local level, the notion of sustainable mobility is often used to justify investments in pedestrian areas, parking policy, and the construction of bicycle tracks. This goes along with the drawing up of Sustainable Urban Mobility Plans (SUMP). Besides policymakers, the public and businesses have embraced the concept of sustainable transport. In many cities, cycling has actually become fashionable, railway station precincts are refurbished, and the car is no longer the sacred cow it was in the 1960s. Some authors have even identified a paradigm shift, in which the smartphone has replaced the car as symbol of a contemporary lifestyle (Davis et al., 2012). Furthermore, we can refer to concepts such as Transit Oriented Development, Smart Growth and compact city policies which have increased in popularity.

In the academic community, sustainability has been a constant theme in academic reflections on transport policy since the early 1990s. To illustrate, in the editorial of the first issue of the journal Transport Policy, Phil Goodwin wrote that the then spirit of the time was characterised 
by sharp debates on sustainability, growth, infrastructure, regulation and power relations, among others, in the transport sector as every other (Goodwin, 1993, p. 3). In line with this statement, the 1993 solutions include land-use control, public transport, road pricing, pedestrian zones and traffic calming, which were all supposed to be context-sensitive remedies. Anyone familiar with transport policy in developed countries will note the similarities with today's sustainable transport agenda. An early overview of sustainable transport-related research is presented by Black and Nijkamp (2002) and 'The sustainable mobility paradigm', published in 2008 by David Banister, has become a classic.

Recently, the 'peak car' phenomenon (Goodwin, 2012) has provoked almost euphoric reactions among sustainable transport activists and researchers who believe that the growth in car ownership and use has come to an end. Broadly speaking, mobility has been growing quasi continuously in the course of time: in 1960, the number of motor vehicles registered in the world was estimated at 127 million, while in 2010 more than 1 billion vehicles occurred in the tables (Davis et al., 2011). However, at least in the Western world, car use might have reached its peak. In the United States, for example, the mileage increased from 1,600 billion in 1983 (when the effect of the then crisis started to wane) to more than 3,000 billion in November 2007, just before the international fuel prices showed an unprecedented peak (Davis and Baxandall, 2013). Since then, the statistics show some decline, and the 2007 mileage level was not reached again.

\subsection{Sustainable transport and its discontents}

But the over two decades old history of sustainable transport includes a considerable number of very critical studies too. It was waiting for the second volume of Transport Policy only, before UK (sustainable) transport policy was critically scrutinized. Owens (1995) argued that replacing the transport engineers' 'predict and provide' paradigm with new panaceas including 'getting the price right', 'planning to reduce the need to travel' and 'major investment in public transport' (ibid., p. 48) had not resulted in a comprehensive and credible policy alternative that goes beyond a mere collection of isolated measures.

One of the fiercest critiques came five years later, when Baeten (2000) stated that 'the orthodox sustainable transport vision actually leads to the further empowerment of technocratic and elitist groups in society while simultaneously contributing to the further disempowerment of those marginalized social groups who were already bearing the burden of the environmental problems resulting from a troubled transport system' (2000, p. 69). Besides equity issues, he also questions whether sustainability-inspired transport policies can improve 
the environment, since such visions unconvincingly attempt to integrate the opposing goals of growth and biophysical limits (Essebo and Baeten, 2012).

Low and Gleeson (2001) point to the same tension between on the one hand, economic development, and on the other, social and environmental protection. They argue that the discourse of economic growth is powerful enough to legitimise unsustainable transport projects, despite the recognition that sustainability is a relevant criterion (among many others). Also Jackson (2009) points out the contradiction between the current economic system, in which growth is necessary to maintain employment levels, and the physical limits of the earth in terms of raw materials, energy and environmental space. Similar claims were also made in the pre-Brundtland era. Although global warming was not yet at stake in 1970, a number of environmental reports from that era that took a global stance sounded far from optimistic compared to the positive communications such as those cited above (in Section 1.1). The oft-quoted report of the Club of Rome (Meadows et al., 1972) argued that the growth of the world population and its consumption would slowly but surely bump against the carrying capacity limits of the earth. And even regardless of the global warming issue, the impending exhaustion of natural resources made the problem outlined very palpable, especially after the outbreak of the first oil crisis in 1973.

\section{Approach}

\subsection{Conceptual focus: sustainability as a category of the good}

In contrast to contributions that mainly focus on how other discourses (e.g. economic growth) neutralise claims for more 'sustainability' (e.g. Low, 2005), the present paper examines policy initiatives in the field of transport that are presented as essentially sustainable, but which nevertheless fail the sustainability test. Within this context, the meaning of 'sustainability' is of prime importance, in order to avoid semantic confusion.

In this contribution, sustainability is understood as a normative concept, as in Neuman's discussion of sustainable urbanism. According to Neuman (2005, p.17), sustainability is ' $a$ category of the good.' since it 'is a debate about how to live.', and the ethical nature needs to be taken into account to avoid dogmatism. The normative nature of 'sustainability' is also acknowledged by Skidelsky \& Skidelsky (2012) who prefer an environmentalism based on ethical values, called good-life environmentalism. Sustainability is, in other words, a debate about the good life. This stands in contrast with the negative interpretation of sustainability in 
the official sustainability discourse which predominantly focuses on climate change and decarbonisation. As the study on 'scientific research about climate change mitigation in transport' by Schwanen et al. (2011) illustrates, a negative perspective on sustainability leaves some fundamental questions unanswered. At the very end of their paper, Schwanen et al. (2011, p. 1004) actually raise the questions 'What is the kind of world that we would like to live in and find desirable and how should mobility be configured in that world?', a question which cannot be answered solely by reference to carbon emission statistics.

The protest against many so-called sustainable transport projects can only be fully understood as a normative critique. Isolated statements on the amount of emissions saved or the percentage of carbon reduction say little about the environment people want to live in (Goldman and Gorham, 2006). Likewise, enthusiasm for cycling and public transport is for a significant part inspired by ideas of a better living environment and way of life, and not simply by the impact on emissions. If this is not understood, sustainable transport debates will necessarily miss the essence. Note that the ethical and normative nature of sustainability does not imply that all opinions are of equal worth; claims need to be reasoned and debated, neither does it ignore the negative effects of climate change.

\subsection{Research focus}

In the remainder of this paper, we will challenge the orthodox sustainable transport vision, by confronting it with two possibly troublesome issues; (1) the urge for growth, and (2) the question of social justice. We will illustrate the paradoxical, often ironic and sometimes even cynical situations to which measures in the field of sustainable transport can lead through a discussion of seven cases from Belgium.

Three stages in the development of a sustainable transport scheme are considered, being (1) the definition of the problem and the selection of indicators (e.g. \% car commuters), (2) the choice of a particular solution (e.g. building a railway line), and (3) the bureaucratic execution and the detailed design of the chosen plan or programme. A number of specific examples from daily transport policy and practice illustrate the mismatch between the orthodox sustainable transport discourse and the aforementioned two aspects of limits to growth and social justice. While many authors take a global approach when assessing transport from a sustainability perspective (Holden et al., 2014; Newman and Kenworthy, 2011), this essay focuses on a limited number of examples from one country. Although the non-quantifiable nature of some of these cases risks to reduce them into merely anecdotical evidence, we argue that it useful and necessary to have the alleged anecdotes documented and 
to have them critically discussed, in order to extend insights gained from them towards other contexts.

The 'peculiar practices' that will be discussed all stem from Belgium, a country with a very strong commuting culture and a traditional tendency towards multimodality within a suburbanized historically polycentric spatial structure. Belgium may be considered fairly representative in terms of mainstream sustainable transport policies, considering the central location of the country, and its engagement in relation to the European Union (Witlox et al., 2013).

\section{A limits-to-growth perspective}

Sustainability is often narrowly defined as 'environmental sustainability' and summarised using a limited number of indicators related to greenhouse gas emissions and pollutants such as particulate matter and $\mathrm{NO}_{\mathrm{x}}$. This section presents four cases which illustrate that so-called 'sustainable transport' policy acts are often problematic, even from an environmental point of view. In other words, even when applying the restricted sustainability focus of these cases, they do not meet their own standards. As will be seen in the discussion, most cases deal insufficiently with the 'limits to growth' question, and remain silent about the tension between economic growth and the earth's carrying capacity.

Table 1 lists the cases which cover the various steps of the policy-making process. The first case focuses on the problem definition and the selection of indicators, in the second case the most problematic issue is the selection of the project, and the third and fourth case illustrate how objectives might change during the design phase of a project.

\begin{tabular}{|l|l|l|}
\hline no. & case/policy act & paradox \\
\hline 1 & $\begin{array}{l}\text { Selecting the most } \\
\text { promising sustainable } \\
\text { transport indicators }\end{array}$ & $\begin{array}{l}\text { Possible stagnation of car travel emissions is offset by } \\
\text { excess consumption in terms of international travel }\end{array}$ \\
\hline 2 & $\begin{array}{l}\text { Improving airport } \\
\text { accessibility by rail }\end{array}$ & $\begin{array}{l}\text { Investments in rail aimed at supporting growth in the air } \\
\text { travel market }\end{array}$ \\
\hline 3 & $\begin{array}{l}\text { Redeveloping Ghent } \\
\text { railway station }\end{array}$ & $\begin{array}{l}\text { Railway station development promotes car access to central } \\
\text { urban amenities }\end{array}$ \\
\hline 4 & $\begin{array}{l}\text { Implementing free bus } \\
\text { transport }\end{array}$ & $\begin{array}{l}\text { Public transport increases its market share by attracting } \\
\text { pedestrians and cyclists }\end{array}$ \\
\hline
\end{tabular}

Table 1. Growth related sustainable transport paradoxes from Belgium

\subsection{Case 1: Choice of indicators to measure trends in transport-related emissions}


In the official Belgian report to the UNFCCC on the greenhouse emissions of interior road transport, an increase of emissions by $31 \%$ in the period 1990-2010 is marked, followed by a decline of $7 \%$ in the period 2010-2014 (NCC, 2016). The report thus suggests that the transport emission peak is behind us. A related plan, the Flemish Climate Policy Plan (LNE, 2013), uses the same kind of indicators and an explicit objective, for instance, is to further increase the share of bicycle use in the modal split. However, it seems unwise to focus on land transport modal split figures and to rely on the hope that the car has passed its peak.

Regarding 'peak car' in Belgium, we see not so much a decline in the growth of the overall distance travelled, but rather a stabilisation of the number of kilometres per inhabitant since 2007, and a slight decrease when counting per registered vehicle (Statistics Belgium, 2014). In other words, the Belgians just continue to buy additional cars, but are driving these less than they would have done before.

Meanwhile, however, it has been demonstrated that the relationship between peak car and peak oil is not unambiguous. Even though at a macroeconomic level, a clear connection between fuel price levels and car use has been demonstrated (Goodwin et al., 2004), price elasticities appear to vary over time and currently have perhaps become subordinate to contextual variables that are entirely unrelated to the oil price on the commodity market (Hughes et al., 2006). This is especially true in a country like Belgium, where the effect of the price mechanism on car consumer behaviour is severely tempered by fuel taxation which is very high in comparison with, for example, the United States or the Middle East (Metschies, 2005).

A number of other developments are at stake as well. Newman and Kenworthy (2011) point out that decline of private motor traffic is mainly recorded in larger cities in North America and in Europe (Kuhnimhof et al., 2013). In some of these cities, including Vienna, Zurich, Brussels and Stockholm, current policies purposefully discourage car traffic by narrowing roads, road pricing, or parking restrictions. However, this does not necessarily mean a reduction of the number of trips: the cities mentioned are known for their traffic growth being shifted towards public transport and cycling.

Official government communications present the outcomes of such policies as a quasistructural slowdown in the growth of domestic travel. We mentioned the official Belgian report to the UNFCCC on the greenhouse emissions of interior road transport which optimistically refers to a decline of 7\% in the period 2010-2014 (NCC, 2016). However, such optimistic figures fail to recognize an important nuance of the peak car discourse. Although continuous growth of surface traffic should no longer be taken for granted in any context, we 
cannot simply transfer the principle to other forms of transport. Just as transport within emerging countries, international trade, and therefore also intercontinental freight transport, keeps growing unabatedly (Essebo and Baeten, 2012). And the same goes for air travel, with an expected annual growth rate of 5\% globally (Schäfer \& Waitz, 2014). In these subsectors, the limits to growth are nowhere near in sight, and this applies also to the associated greenhouse gas emissions or consumption of fossil fuels.

Although in the developed world the growth of car traffic may start to collide with spatial and environmental constraints, the human desire for ever more interaction with the world seems to translate into a choice for ever faster means of transport, of which the exploding air travel market is the ultimate outcome (Bleijenberg, 2003). As in similar European countries, the daily distances travelled in Belgium are (seemingly) meticulously registered, particularly concerning the commute. This is in stark contrast to the way air travel behaviour of Belgian citizens is monitored. Although the airports do publish passenger numbers, no specific data is provided on airmiles travelled and the associated greenhouse gas emissions by air travellers using Belgian airports.

Boussauw (2009) did a (fairly rough) estimate of energy consumption associated with the flight behaviour of the Flemish (58\% of the Belgian population) for the year 2008. Despite the fact that $53 \%$ of the Flemish population (figure from 2001) pretend never to fly, the total annual energy volume consumed through air trips by the Flemish (about 69 PJ) amounts more than half of the energy consumed in domestic (non-air) travel (122 PJ).

When looking at the impact on global warming, the balance is even more to the detriment of aviation. Due to cloud formation, one litre of fossil fuel that is burned at high altitude contributes disproportionally more to global warming compared to burning that same litre near see level: Åkerman (2005) mentions a factor of 2.7 to be applied, which would mean that the climate impact by Flemish air travellers in 2008 was more than $50 \%$ higher than the impact of domestic (non-air) travel. In Belgium, the airline industry today draws growth rates of 4.8\% (average annual growth between 2007 and 2014 (Statistics Belgium, 2016)), while the Belgian GDP in the same period showed an average annual growth as little as $0.6 \%$ (NBB, 2016).

This case is an illustration of an incomplete problem definition (step 1 in Section 2.2). In national (but also local) statistics, the climate-transport issue is reduced to domestic travel, while aviation (as well as international shipping) is not even recognized as being part of the climate problem. The Flemish Climate Policy Plan (LNE, 2013) for example, contains no measures related to air travel, while encouraging bike travel is supposed to be part of the 
solution. Indicators (step 1) pointing to stagnation in the growth of domestic travel are missing the point to an important extent, just as the measures that are subsequently proposed (step 2).

\subsection{Case 2: Improving airport access by rail}

Given the huge global environmental impact of air transport, which is hardly recognized in most transport related policy plans, it is no coincidence that air travel is also present in the next case. In 2004, a new access plan for Brussels Airport was decided on. Although at the time, the airport had already a rail connection with the capital, a second and a third rail branch were planned to connect Antwerp (in the north) and Leuven (in the east) as well. These investments were supposed to contribute to the expansion of the airport, offering an alternative to using the congested motorways near the airport. According to transport economic theories, increasing the accessibility of an airport makes it more attractive for both travellers and airline companies. Since aircraft may be considered among the least efficient forms of transport when it comes to emissions and fuel consumption (UNWTO, 2008), investments in airport accessibility will likely increase emissions over time. However, the federal government clearly thought otherwise. In 2008, the new rail access projects were included in the federal climate accounts, in which it was simply assumed that any new rail passenger is a former car driver (National Climate Commission, 2008, p. 58). So there would be fewer cars on the road, and part of the climate goals would be achieved. Despite the highly questionable nature of this assumption, the effect of the measure was never monitored. The new rail link was opened in June 2012, and between 2012 and 2014, the number of passengers that departed from Brussels Airport rose by $16 \%$, which was considerably higher than growth rates at other Belgian airports. It is not imaginary that the better accessibility of the airport played a role in this development, given the recently (slightly) increased modal share of the train in airport access. In 2013, these growing passenger numbers were used as an argument to reopen the debate about a new motorway access to the airport in the direction of Leuven anyway.

Although this case was positively evaluated in the national greenhouse gas emission accounts, the choice to improve accessibility to a major 'emission generator' works, by its very nature, against environmental sustainability. The main issue thus relates to the second step in the policy process (Section 2.2), the selection of projects. Apart from the nature of the project, the sometimes implicit assumption that rail is by definition environmentally sustainable, leads to a biased selection of indicators (step 1). 


\subsection{Case 3: Redevelopment of Ghent railway station}

In the city of Ghent we observe a similar paradox in the redevelopment of the central station area. In the context of the Spatial Structure Plan for Flanders, an overarching vision for the sustainable spatial development of the Flemish region, efforts have increasingly been geared towards upgrading the precincts of the main railway stations (RSV, 1997[2004]). By creating density and functional diversity in areas that are well served by public transport, local modal split adjustments towards public transport where hoped for. Near the Ghent railway station, which is one of the three largest Belgian stations in terms of passenger numbers $(45,000$ passengers a day, planned to increase to 60,000 (NMBS, 2014)), a large-scale programme was developed including apartments, offices, all kinds of amenities, and a large car park. The construction of the 2800 vehicle car park fitted explicitly in a programme to encourage train use by long-distance commuters (Coppens, 2010). Employees living in Ghent's suburbs, which were used to go to work by car, would henceforth be able to leave their car at the station to travel to their office in Brussels or elsewhere by train. This would lead to considerable savings in terms of $\mathrm{CO}_{2}$ emissions. However, the local environmental movement was sceptical of the plan, and a couple of years after the opening of the car park, it organized a user survey. The survey results showed that only a very small minority (four out of one hundred surveyed parkers) had indeed switched to rail for their long haul (as could have been expected on the basis of studies reported in the Park and Ride literature (Zijlstra et al., 2015)). However, the majority of the users of the car park consisted of commuters who previously arrived by a local train, or by bus or tram before taking the express train in the station. Therefore, the construction of the car park had led to more car use, instead of less. In addition, the parking has contributed to a local concentration of particulate matter production in the surrounding residential area (GMF, 2012).

Referring back to the three types of policy acts mentioned in Section 2.2, the project design, in particular the large car park, is not consistent with the original problem definition that was developed around car dependency. Regarding indicators, although reducing the number of vehicle kilometres travelled could have been a logical target, emphasis was shifted towards maximizing the number of station users, resulting in an increase in car traffic in the neighbouring residential areas.

\subsection{Case 4: Free bus transport}


In 1997, the regional city of Hasselt introduced a subsidy in order to make access to the city bus network free of charge for all passengers, a situation which would last for the next seventeen years. After the introduction of the measure, as expected, the number of bus passengers increased to an important extent. However, a survey found that of all additional bus passengers, only $16 \%$ would have taken the car in case the bus would not have been for free. Six out of ten additional bus passengers would simply have stayed at home, and another two out of ten would otherwise have been walking or cycling (Van Goeverden et al., 2006). In the university city of Leuven, between 2001 and 2013, free buses where offered to the student population. Again, an important shift from bicycle towards bus was noticed. In Leuven too, the subsidy caused an increase in demand and a need for more buses, making it unlikely to meet the original sustainability targets.

Although substitution effects towards pedestrians and cyclists could have been expected on the basis of internationally published research (see e.g. Callaghan \& Vincent (2007)), in the Hasselt case it was mainly the number of newly generated trips that was rather impressive. The political initiators of the free transit initiative did not find this outcome in contradiction with their original social objectives, since some groups had apparently become more mobile, while buses showed higher occupancy rates.

However, the original objective's part about reducing car use was barely realized. Again, a goal displacement is at stake: since it became clear that the measure did not lead to the desired result (reducing car use), while other effects, which might also have been desirable (increasing the freedom of movement of some groups), occurred, the project was reframed and considered successful. Paradoxically, an intervention that was partly aimed at halting the growth of local traffic, has in practice led to accelerated growth in the number of trips.

\section{A social justice perspective}

The last case discussed in the previous section, free bus transport, might cause negative environmental effects, however, the social impact can be positive (see e.g. Goodman et al., 2014). Since we argued in favour of a broad perspective on sustainability, this section discusses a number of social impacts of 'sustainable transport' policy acts. Indeed, the development of a transport system which is overall less environmentally harmful does not guarantee a fair distribution of access to transport and to full participation in society by itself. While this argument may not apply to all facets of the orthodox sustainable transport vision, it 
is indeed likely that positive interventions in planning may only affect those who are in the position to have their voices heard, while technological solutions seem to be first and foremost reserved to those who can afford it. Through careless implementation of sustainability-aimed transport policies, we risk excluding vulnerable groups in society.

The orthodox sustainable transport vision usually favours public transport in general, and rail in particular. However, attempts to attract new customers by investing in suburban commuter rail projects might result in the neglect of poor transit dependents in city centres. In such occasions, public transit is promoted as a solution for congestion and air pollution problems, and thus not as a social service (Garrett and Taylor, 1999). Today, the focus has been shifting to the development of large-scale rail infrastructure, which usually focuses on improving access to job concentrations in the larger conurbations, and connecting these with each other by means of fast trains. While such projects are usually viewed as sustainable, they are still mainly serving members of the hyper-mobile society, usually highly educated and often male. The needs of socially vulnerable groups, which are rather located in the sphere of buses, transport on demand, and dense networks of facilities close to home, are much less evident in this discourse. The outlined dynamics usually apply in the context of an urban area. But also at the regional scale, the orthodox approach to sustainability is not always compatible with social justice, as we will note from the cases discussed in the next subsection. The cases discussed below are summarized in Table 2. Each case illustrates a particular type of strategy, namely: (1) inducing a green modal shift in the commute, (2) changing vehicle characteristics, and (3) reducing fuel consumption.

\begin{tabular}{|l|l|l|}
\hline no. & case/policy act & paradox \\
\hline 5 & $\begin{array}{l}\text { Supporting green } \\
\text { commuting using } \\
\text { fiscal and financial } \\
\text { incentives }\end{array}$ & $\begin{array}{l}\text { Subsidies aimed at improving labour market access are } \\
\text { mainly harvested by the well-off }\end{array}$ \\
\hline 6 & $\begin{array}{l}\text { Banning 'dirty' } \\
\text { vehicles and } \\
\text { subsidising clean ones }\end{array}$ & $\begin{array}{l}\text { Older cars are mainly used by lower income groups while } \\
\text { electric vehicles are for the elite }\end{array}$ \\
\hline 7 & $\begin{array}{l}\text { Taxing fuel } \\
\text { consumption and } \\
\text { kilometres travelled }\end{array}$ & Poorer regions induce long commutes \\
\hline
\end{tabular}

Table 2. Social justice related sustainable transport paradoxes from Belgium

\subsection{Case 5: Fiscal and financial support for green commuting modes}


Belgium has a long tradition of commuter subsidies which influence travel patterns in questionable ways. Already in the nineteenth century, cheap rail season tickets were offered to workers, supporting a suburban commuter system and purposely limiting urbanization (Dujardin et al., 2012; De Decker, 2011). In 2004 the third party payment system was introduced, which meant that almost all staff in the public sector and part of the private sector were allowed to take the train and the bus to work entirely free of charge and tax-exempt, the cost being borne by the employer and the public purse (Belgisch Staatsblad, 2004). The social-democratic coalition partner in particular communicated this measure as being in favour of sustainable mobility. It was argued that a considerable number of employees would change towards public transport instead of going by car, for which they would have to pay themselves. Official communication did not mention that the measure was largely covering those who were already using public transport, for example because they work in the centre of Brussels or another large city. While rail commuters are on average more affluent than other commuters (Cornelis et al., 2012), within the group of public transport commuters, the odds of being fully reimbursed is significantly lower for blue-collar workers $(0.50)$ when compared to teachers, officials and executive staff $(1.17$; odds ratio $=0.43){ }^{2}$

Besides, in 1999, a bicycle mileage allowance was made tax exempt and had already been introduced to many employees commuting by bike (Belgisch Staatsblad, 1999). Since cycling was considered the most sustainable form of travel, it is argued that the cost of bicycle maintenance and specific clothing would no longer have to be borne by the employee. Similarly to the rail case, within the group of commuters whose main commuting mode is the bicycle, blue-collar workers less often indicated that their employer bears all commuting costs (odds: 0.08 , compared to 0.35 for the reference category). ${ }^{3}$

However, government support for both rail and bike commuting cannot be seen in isolation from Belgium's attitude to commuting expenses in general. Over the last decades, the historical support for rail commuting was extended to car commuters, in the form of a tax deduction for commuting expenses and company cars. In particular the fiscal treatment of company cars is very selective, since it only includes that class of staff that can claim a company car, and this tax deduction is generally seen as a compensation for the high taxation of labour (Vanoutrive et al., 2010; Zijlstra et al., 2014). With this combination of measures,

\footnotetext{
2 Numbers based on a weighted logistic regression using the svyglm function in the R package 'survey', significant at 0.05 level. Data: year 2010, Belgium, $\mathrm{n}=855$, BELDAM database see Cornelis et al. (2012). 3 Similar model as for transit commuters, $n=244$, estimate for blue-collar worker dummy variable significant at 0.05 level; reference: teachers, officials and executive staff.
} 
eventually almost the entire continuum of travel to work seems to be covered, which compelled the OECD in 2013 to severely criticize Belgium's commuter policy because it was apparently subsidizing every mode of transport: car, train, bus, tram and bicycle (OECD, 2013).

OECD's criticism regarding the lack of distinction between travel modes was certainly justified, but what was conveniently overlooked is the fact that most of the subsidies might essentially end up with higher income groups. Private and public employers offer their company vehicles and fuel passes usually only to executive and representative staff members, in contrast to labour class workers and assisting or cleaning staff. In the public sector, jobs with above average salaries are typically located in large urban areas, such as Brussels, where the train is the most efficient means of transport. Less well-paid jobs in the public sector, e.g. in education, health care, maintenance or support services, are often found in places where public transport is hardly a real alternative, e.g. due to low service frequencies. So, public sector employees in decentralized locations are often obliged to cover a substantial part of their own (car) commute expenses. In short, commuting subsidies, whether targeted to sustainable mobility or not, mainly reach the middle class. The Sustainable Development Commission (2011, p.7) reached similar conclusions for the UK, stating that 'The richest 10 per cent of the population effectively receive four times as much public spending on transport as the poorest 10 per cent.'

Regarding the problem definition and the selection of indicators, we mentioned earlier that narrowing the transport problem to one of supporting 'sustainable' modes of transport is too restrictive. Furthermore, at the design stage, the assumption that the 'right' incentives will induce a shift from the car to more sustainable travel modes is overly optimistic, especially since the system supports commuting by car as well. Finally, the current system cannot be justified as beneficial for low-income groups.

\subsection{Case 6: Measures influencing vehicle characteristics}

In the city of Antwerp, from February 1st, 2017, a low-emission zone will be in force. Diesel vehicles without particulate filter or not meeting the Euro 3 standard will no longer be allowed in the city, just as gasoline vehicles that do not meet the Euro 1 standard, or that were built before 1992. This new regulation is much stricter than e.g. the London low emission zone, which focuses on trucks only. Antwerp's low emission zone is more similar to the German system (Morfeld et al., 2014), with the major difference that in Antwerp access restrictions may temporarily be redeemed for a fee. 
It is striking that the measure unambiguously intends to remove older cars from the streets, without taking into account that drivers of newer (and especially company) cars travel more kilometres per year. Under the first phase of the new regime, cars that were built before 1992 are not allowed to enter the city, unless the driver buys a day pass. Interestingly, the day pass is available at bargain price for classic cars older than 40 years. A regional motorist's organization indicated that $56 \%$ of all inner-urban Antwerp diesel car owners should have replaced their vehicle by a new one before 2020 (when the second phase starts) (VAB, 2015). Part of Antwerp's poorer population might not be able to carry such an investment, especially not when considering the expected negative impact on the resale value of the vehicles that are excluded by the low emission scheme. The negative redistributive effect is additionally reinforced by the so-called ecoscore system, which ensures employees using an - usually ecoscore compliant - company car to always have access to the low-emission zone. Note again that company cars in Belgium are largely a privilege of middle and higher class employees of the private sector.

One side of the vehicle characteristics coin is the ban on 'dirty' cars, the other side is the support for clean vehicles. From January 1, 2010 onwards, tax deduction of company cars in Belgium are based on the vehicle's $\mathrm{CO}_{2}$ emissions. This means that in accounting, very economical cars on diesel or gasoline may be deducted from taxable revenues at a rate of $100 \%$, while electric car expenses may be deducted at a rate as high as $120 \%$, which should be regarded as a substantial subsidy. Since the tax deduction system is proportional, this also meant that expensive electric cars would receive a larger subsidy compared to more democratic, small electric cars. In the first months after the introduction of the new tax regime, eight out of the fifteen electric cars that were sold in Belgium where Tesla Roadster, which then cost around 84,000 euros (Mobimix, 2010). These sports cars were sold to company managers which were looking for an ecological showcase for their business. The Tesla Roadster was characterized by a zero local emission rate, an incredible acceleration potential, space for one passenger at max, and the quasi absence of a trunk. Although the assortment of electric cars sold in the following years would better correspond with the image of the zero-emission car as an efficient, useful and responsible vehicle, the Tesla sports car may have become an icon of the discrepancy between a techno-optimistic sustainability discourse and the pursuit of social justice.

In this case we are faced again with a too narrow definition of the problem, through which only emissions at the level of the individual vehicle are being questioned. As a consequence, the solution is reduced to the replacement of old vehicles, or to subsidizing a specific 
technology, which is consequently positioned in the market by means of a luxury product. Although here we should not necessarily speak about goal displacement, it is nevertheless clear that the activity of subsidizing luxury cars with public funds might have overlooked a number of possible social objectives related to sustainable transport.

\subsection{Case 7: Targeting fuel consumption}

In 2003 the so-called cliquet system for diesel fuel was introduced in Belgium, which meant that declines in the international oil price were partially offset by an increase in excise duties levied on diesel fuel. This system was defended on the basis of environmental arguments, while at the same time it was a strategy to raise federal tax income. Although this system was changed several times and partly scaled back, it is characteristic of a philosophy in which long distance car travel is relatively heavily taxed.

Since April 2016, in Belgium an additional kilometre tax is in effect for lorries over 3.5 tonnes, and several policy-makers publicly stated that they want to extend the system to cars. Although both measures can be defended from an environmental perspective - directly targeting fuel consumption or the related travel distances - there has been remarkably little debate about the impact of these measures on social justice and welfare redistribution. However, there are good reasons to pay attention to such arguments, as is acknowledged in the literature (see e.g. Levinson, 2010 on equity and road pricing, Cesaroni et al., 2012 on the impact of low-emission zones by socioeconomic position, and Lucas (2004) on transport poverty).

With respect to distance-related taxation systems, it is known - although not acknowledged that in Belgium an average inhabitant of the Walloon region (south of the country) has a longer drive to work than his Flemish compatriot (in the north). Those five Belgian municipalities exhibiting the highest average commuting distance (in the order of $40 \mathrm{~km}$, oneway) are without exception in remote locations in the south of the country where incomes are below average. Those municipalities with the lowest average commuting distance (around 10 $\mathrm{km}$ ) are located in Brussels and in the south of West Flanders, two regions showing high levels of employment supply (Verhetsel et al., 2007). Similar divides have been observed in the United States, where residents of poorer states travel, or need to travel, greater distances compared to residents of wealthier states (Baxandall, 2013). In both cases, this means that in some less prosperous regions, people are required to spend a disproportionate share of their salary on transport, at least if they want to be assured of a certain level of income and accessibility. Although such tax-related issues cannot be seen in isolation from the fiscal 
treatment of commuting expenses, it is clear that the inhabitants of the wealthiest municipalities in Belgium (typical suburban areas near large cities) are barely affected by the charges mentioned.

In this case the transport problem has been reduced to an environmental problem in the strict sense; it is defined in terms of air quality and carbon emissions caused by vehicles. In the current way of thinking about distance-based taxation, but also low emission zoning, the question of the impact on the vulnerability of population groups that depend on long-distance commuting for their income is not taken into account.

\section{Discussion}

In the previous sections, seven cases were presented that illustrate how 'sustainable transport' measures can work against sustainability. The reasons for this are to be found in (1) the restricted and biased problem definition and the subsequent selection of indicators, (2) the choice for inherently 'unsustainable' solutions, and (3) goal displacements during the execution phase. As a result, while sustainable transport has become a common notion in policy documents at all levels, it is seldom more than symbolic politics (Happaerts, 2012), despite the presence of measures supporting more sustainable modes of transport, cleaner vehicles, and lower fuel consumption. The aim of this paper was to illustrate how this popular discourse translates into questionable outcomes. This discussion section considers following aspects at a more general level: (1) the field of tension between growth and environmental protection, and (2) the relation with social protection.

\subsection{Sustainable transport and biophysical limits}

What is present in most of the seven cases is the idea that there exist 'sustainable' modes of transport that need to be promoted to make them more competitive vis-à-vis the car. While emission levels of alternative modes of transport are often lower on a per kilometre basis, the policy discourses remain silent on the switch of former cyclists to transit, trip lengthening, the role of transit as a feeder mode for air travel, and potential regressive effects. Let it be clear that anyone who talks about climate change and transport without talking about aviation misses an important dimension. Since in such a debate with a global scope, it would be much less far-reaching to neglect the bicycle. The restriction of the focus to relative numbers and a strategic selection of trips (changes concerning particular segments without taking into 
account wider impacts or air travel) are instrumental to offer an optimistic account of sustainable transport, and to neutralise the growth issue.

Growth in mobility seems inherent to present-day society, in which the increase of travel speed can be seen as the equivalent of the increasing efficiency that is typical of a growing economy. The parallel with the issue of economic growth, and its possible limits, can hardly be denied. Although in his study "Prosperity Without Growth" (2009) Tim Jackson does his utmost to show that the statement reflected by the title of his book is a real option, he only partially succeeds in this. Since increased efficiency is inherent in our system, less and less effort is needed to maintain the same standard of living. If we want to stay at work all together, this means that either we need to produce more (with the same amount of labour), either we should work fewer hours in total (Skidelsky and Skidelsky, 2012). But even more free time leads to more consumption, and the desire for more and better of anything seems to be a structural feature. And even though in the global north the degree of saturation at which more consumption no longer equates with more happiness has been reached yet, in most of the world this is still far from being true (Inglehart and Klingemann, 2000). Better than any theory, the cases demonstrate that perhaps the growth of mobility is much more intertwined with the present structure of society than experts and activists would like to admit.

From time to time car manufacturers show off with new, high efficiency 'concept cars'. But in reality, the fuel consumption of new cars sold in the world is hardly, if at all, going down (Chiara and Canova, 2013). Recently, the market for large cars has only steadily increased, and in smaller cars, part of the potential energy savings are offset by the presence of a range of new gadgets. Furthermore, replacing a thirsty car with a more efficient one does not mean that the old car is removed from the market: used vehicles remain a prized import product in many Third World countries, even the less fuel efficient ones.

\subsection{Sustainable transport and social justice}

As some of the cases discussed indicate, the sustainable transport discourse may be used to support policies that are potentially socially inequitable. However, also the distribution of the environmental burden of, among other things, transport activities may be unjust, as the environmental justice literature maintains. Although the size and even the sign of effects varies across cities and regions, there is some evidence that low-income and minority communities are exposed to higher levels of noise and air pollution (Schweitzer and Valenzuela, 2004). This is one side of the (distributive) justice coin. The other side concerns the morally proper distribution of transport benefits (Martens, 2006, 2012). 
But then the question remains, what transport policy measures are just, fair or equitable? This brings us to the normative nature of sustainability; it is not just about what we don't want, but also about the environment people want to live in. Although there is no shortage of visualisations of attractive state of the art HSR railway stations and neighbourhoods designed on the basis of the principles of TOD - indicating a positive stance - social inclusion is often not the main concern. In contrast, inclusion is a core concept in part of the accessibility literature, which emphasizes that people need access to activities and facilities in order to fully participate in society (Cass et al., 2005; Martens, 2012; Preston and Raje, 2007; Farrington, 2007; Farrington and Farrington, 2005). Reconciling accessibility with sustainability requires proximity and this might require rethinking consumption and production patterns. Several existing ideas about sustainable mobility dovetail with the accessibility narrative, even though the contribution to social justice is often not explicitly mentioned.

It might be a good idea to continuously favour the use of public transport and bicycles in cities. Even though the expected impact on greenhouse gas emissions is only little, such policies will contribute to the quality of life of those living in urban areas, especially with respect to the socially weakest. This does not mean that all vulnerable groups will benefit from car discouraging policies, but by offering public transport and bicycle paths as a public service, all segments of the population would face additional travel opportunities. Road safety too can benefit from such measures, while compact urban planning may improve accessibility by limiting distance between origins and destinations of journeys.

\section{Conclusions}

The rise of the concept of sustainability has considerably changed transport policy and research. In this essay, we critically evaluated some Belgian cases where sustainable transport rhetoric was used to legitimate policies with questionable outcomes. These cases illustrate the paradox of the sustainability discourse having a real impact on the design of policies, while at the same time leaving behind a number of dissatisfied actors, which are unconvinced of such policy's contribution to sustainable development of society as a whole. Such a prolonged dissatisfaction can only be understood by recognising the normative nature of sustainability. Several cases illustrate how 'sustainable transport' policies invest in projects that might result in more pollution and carbon emissions. However, we may not solely focus on the negative 
side, the harmful effects of transport, but also on the positive side. Indeed, 'sustainability' is a debate about the environment people want to live in and about the transport possibilities they need and want in this environment. This debate is not restricted to transport, as it was argued that the sustainable transport paradigm has not yet come to terms with the incompatibility of sustainability and the potentially systemic urge for growth.

\section{References}

Åkerman, J. (2005). Sustainable air transport: on track in 2050. Transportation Research Part D: Transport and Environment, 10(2), 111-126.

Baeten, G. (2000). The tragedy of the highway: Empowerment, disempowerment and the politics of sustainability discourses and practices. European Planning Studies, 8(1), 69-86.

Banister, D. (2008). The sustainable mobility paradigm. Transport Policy, 15(2), 73-80.

Baxandall, P. (2013). Moving Off the Road: A State-by-State Analysis of the National Decline in Driving. Boston: USPIRG Education Fund.

Belgisch Staatsblad. (1999). Koninklijk Besluit van 20 april 1999 houdende toekenning van een vergoeding voor het gebruik van de fiets aan de personeelsleden van sommige overheidsdiensten. Belgisch Staatsblad - Moniteur Belge, (April 29th).

Belgisch Staatsblad. (2004). Koninklijk Besluit houdende goedkeuring van het vierde bijvoegsel bij het tweede beheerscontract van de Nationale Maatschappij der Belgische Spoorwegen. Belgisch Staatsblad - Moniteur Belge, (August 27th).

Black, W. R., \& Nijkamp, P. (2002). Social Change and Sustainable Transport. Bloomington, Indiana: Indiana University Press.

Bleijenberg, A. (2003). The driving forces behind transport growth and their implications for policy. In ECMT (Ed.), Managing the Fundamental Drivers of Transport Demand (pp. 3750). Paris: European Conference of Ministers of Transport.

Boussauw, K. (2009). Stadsmens onderweg: een duurzaamheidsparadox. Agora, 25(5), 7-10.

Bulkeley, H., \& Betsill, M. (2005). Rethinking sustainable cities: multilevel governance and the "urban" politics of climate change. Environmental Politics, 14(1), 42-63.

Callaghan, L., \& Vincent, W. (2007). Preliminary evaluation of Metro Orange Line bus rapid transit project. Transportation Research Record, 2034, 37-44.

Cass, N., Shove, E., \& Urry, J. (2005). Social exclusion, mobility and access. Sociological Review, 53(3), 539-555.

Cesaroni, G., Boogaard, H., Jonkers, S., Porta, D., Badaloni, C., Cattani, G., ... Hoek, G. (2012). Health benefits of traffic-related air pollution reduction in different socioeconomic groups: the effect of low-emission zoning in Rome. Occupational and Environmental Medicine, 69(2), 133-139.

Chiara, F., \& Canova, M. (2013). A review of energy consumption, management, and recovery in automotive systems, with considerations of future trends. Proceedings of the Institution of Mechanical Engineers, Part D: Journal of Automobile Engineering, 227(6), 914-936.

Coppens, T. (2010). Understanding land use conflicts in strategic urban projects: lessons from Ghent Sint Pieters. In S. Oosterlynck, J. Van den Broeck, \& L. Albrechts (Eds.), Strategic Spatial Projects: Catalysts for Change (pp. 189-211). Oxon: Routledge. 
Cornelis, E., Hubert, M., Huynen, P., Lebrun, K., Patriarche, G., De Witte, A., ... Walle, F. (2010). La Mobilité en Belgique en 2010: Résultats de l'enquête Beldam. Brussels: Belspo and FPS Mobility \& Transport.

Davis, B., \& Baxandall, P. (2013). Transportation in Transition: A Look at Changing Travel Patterns in America's Biggest Cities. Boston: USPIRG Education Fund.

Davis, B., Dutzik, T., \& Baxandall, P. (2012). Transportation and the New Generation: Why Young People Are Driving Less and What It Means for Transportation Policy. Boston: Frontier Group \& USPIRG Education Fund.

Davis, S. C., Diegel, S. W., \& Boundy, R. G. (2011). Transportation Energy Data Book. Oak Ridge, TN: Oak Ridge National Laboratory.

De Decker, P. (2011). Understanding housing sprawl: the case of Flanders, Belgium. Environment and Planning A, 43(7), 1634-1654.

Dujardin, S., Boussauw, K., Brévers, F., Lambotte, J.-M., Teller, J., \& Witlox, F. (2012). Sustainability and change in the institutionalized commute in Belgium: exploring regional differences. Applied Geography, 35(1-2).

Essebo, M., \& Baeten, G. (2012). Contradictions of "sustainable mobility": the illogic of growth and the logic of myth. Tijdschrift Voor Economische En Sociale Geografie, 103(5), $555-565$.

Farrington, J., \& Farrington, C. (2005). Rural accessibility, social inclusion and social justice: towards conceptualisation. Journal of Transport Geography, 13(1), 1-12.

Farrington, J. H. (2007). The new narrative of accessibility: its potential contribution to discourses in (transport) geography. Journal of Transport Geography, 15(5), 319-330.

Garrett, M., \& Taylor, B. (1999). Reconsidering social equity in public transit. Berkeley Planning Journal, 13(1), 6-27.

GMF. (2012). Openbaar vervoer richting Gent-Sint-Pieters onvoldoende concurrentieel met parking. Retrieved from http://www.gentsmilieufront.be/index.php/id/777? access date 24/5/2016.

Goldman, T., \& Gorham, R. (2006). Sustainable urban transport: Four innovative directions. Technology in Society, 28, 261-273.

Goodman, A., Jones, A., Roberts, H., Steinbach, R., \& Green, J. (2014). "We can all just get on a bus and go": rethinking independent mobility in the context of the universal provision of free bus travel to young Londoners. Mobilities, 9(2), 275-293.

Goodwin, P. (1993). Editorial: Briding the gap. Transport Policy, 1(1), 3-5.

Goodwin, P., Dargay, J., \& Hanly, M. (2004). Elasticities of road traffic and fuel consumption with respect to price and income: a review. Transport Reviews, 24(3), 275-292.

Goodwin, P. (2012). Three views on peak car. World Transport, Policy \& Practice, 17(4), 8 17.

Hajer, M. A. (1995). The Politics of Environmental Discourse: Ecological Modernization and the Policy Process. Oxford: Clarendon.

Happaerts, S. (2014). Sustainable development and subnational governments: Going beyond symbolic politics? Environmental Development, 4, 2-17.

Holden, E., Linnerud, K., \& Banister, D. (2014). Sustainable development: Our Common Future revisited. Global Environmental Change, 26, 130-139.

Hughes, J. E., Knittel, C. R., \& Sperling, D. (2006). Evidence of a shift in the short-run price elasticity of gasoline demand. Berkeley, CA: Center for the Study of Energy Markets University of California.

Inglehart, R., \& Klingemann, H.-D. (2000). Genes, Culture and Happiness. Boston, MA: MIT Press.

Jackson, T. (2009). Prosperity without Growth: Economics for a Finite planet. London: Earthscan. 
Kuhnimhof, T., Zumkeller, D., \& Chlond, B. (2013). Who made peak car, and how? A breakdown of trends over four decades in four countries. Transport Reviews, 33(3), 325342.

Levinson, D. (2010). Equity effects of road pricing: a review. Transport Reviews, 30(1), 3357.

LNE. (2013). Vlaams Klimaatbeleidsplan 2013-2020. Brussels: Flemish Government, Environment, Nature, and Energy Department.

Low, N. (2005). The Gordian knot: Resisting sustainability in urban transport in Australia. In K. Williams (Ed.), Spatial Planning, Urban Form and Sustainable Transport (pp. 171182). Aldershot: Ashgate.

Low, N., \& Gleeson, B. (2001). Ecosocialization or countermodernization? Reviewing the shifting "storylines" of transport planning. International Journal of Urban and Regional Research, 25(4), 784-803.

Lucas, K. (2004). Running on Empty: Transport, Social Exclusion and Environmental Justice. Bristol: Policy Press.

Martens, K. (2006). Basing transport planning on principles of social justice. Berkeley Planning Journal, 19(1), 1-17.

Martens, K. (2012). Justice in transport as justice in accessibility: applying Walzer's "spheres of justice" to the transport sector. Transportation, 39(6), 1035-1053.

Meadows, D. H., Randers, J., Meadows, D. L., \& Behrens, W. W. (1972). The Limits to Growth: A Global Challenge. New York: Universe Books.

Meersman, H., Van de Voorde, E., Macharis, C., Vanelslander, T., Sys, C., De Langhe, K., ... Van Hassel, E. (2013). Indicatorenboek 2012: Duurzaam Goederenvervoer Vlaanderen. Antwerp: Policy Research Centre on Commodity ad Passenger Flows (MOBILO).

Metschies, G. P. (2005). International Fuel Prices 2005. Eschborn: Deutsche Gesellschaft für Technische Zusammenarbeit (GTZ).

MIRA. (2013). CO2-emissie van nieuwe personenwagens.

Mobimix. (2010). 15 elektrische wagens verkocht in België. Retrieved from http://www.milieurapport.be/nl/feitencijfers/sectoren/transport/emissie-naar-lucht-doortransport/co2-emissie-van-nieuwe-personenwagens/? access date 24/5/2016.

Morfeld, P., Groneberg, D. A., \& Spallek, M. F. (2014). Effectiveness of low emission zones: large scale analysis of changes in environmental $\mathrm{NO}_{2}, \mathrm{NO}$ and $\mathrm{NO}_{\mathrm{x}}$ concentrations in 17 German cities. PLOS ONE, 9(8), 1-18.

National Climate Commission. (2008). Nationaal Klimaatplan van België / Plan National Climat de la Belgique 2009-2013. FPS Public Health, Food Chain Safety and Environment.

NBB. (2016). Quarterly and annual aggregates: GDP growth. Brussels: National Bank of Belgium Online Statistics. Retrieved from http://stat.nbb.be/, access date 24/5/2016.

NCC. (2016). Greenhouse gas inventory for Belgium - submission 15 April 2016. Brussels: National Climate Commission - Belgium. Retrieved from http://cdr.eionet.europa.eu/be/eu/mmr/art07_inventory/ghg_inventory/envvxcqwq/, access date $24 / 5 / 2016$.

Neuman, M. (2005). The compact city fallacy. Journal of Planning Education and Research, 25(1), 11-26.

Newman, P., \& Kenworthy, J. (2011). "Peak car use": understanding the demise of automobile dependence. World Transport Policy and Practice, 17, 31-42.

NMBS. (2014). Project Gent Sint-Pieters. Retrieved from http://www.projectgentsintpieters.be/, access date 24/5/2016.

OECD. (2013). OECD Economic Surveys: Belgium 2013. Paris: Organisation for Economic Co-operation and Development. 
Owens, S. (1995). From "predict and provide" to "predict and prevent"?: pricing and planning in transport policy, 2(1), 43-49.

Preston, J., \& Rajé, F. (2007). Accessibility, mobility and transport-related social exclusion. Journal of Transport Geography, 15(3), 151-160.

RSV. (2004). Ruimtelijk Structuurplan Vlaanderen. Brussels: Ministry of the Flemish Community.

Schäfer, A. W., \& Waitz, I. A. (2014). Air transportation and the environment. Transport Policy, 34, 1-4.

Schwanen, T., Banister, D., \& Anable, J. (2011). Scientific research about climate change mitigation in transport: a critical review. Transportation Research Part A, 45(10), $993-$ 1006.

Schweitzer, L., \& Valenzuela, A. (2004). Environmental injustice and transportation: the claims and the evidence. Journal of Planning Literature, 18(4), 383-398.

Sheller, M., \& Urry, J. (2006). The new mobilities paradigm. Environment and Planning A, 38(2), 207-226.

Skidelsky, R., \& Skidelsky, E. (2012). How Much Is Enough? The Love of Money, and the Case for the Good Life. Harlow: Penguin Books - Allen Lane.

Statistics Belgium. (2014). Verkeer en vervoer. Brussels: FPS Economy. Retrieved from http://statbel.fgov.be/nl/statistieken/cijfers/verkeer vervoer/, access date 24/5/2016.

Statistics Belgium. (2016). Air Transport. Brussels: FPS Economy. Retrieved from http://statbel.fgov.be/nl/statistieken/cijfers/verkeer_vervoer/vervoer/luchtvaart/, access date 24/5/2016.

Sustainable Development Commission. (2011). Fairness in a Car-Dependent Society. London: Sustainable Development Commission.

Tight, M. R., Delle Site, P., \& Meyer-Rühle, O. (2004). Decoupling transport from economic growth: towards transport sustainability in Europe. European Journal of Transport and Infrastructure Research, 4(4), 381-404.

UNWTO. (2008). Climate Change and Tourism: Responding to Global Challenges. Madrid: World Tourism Organization.

VAB. (2015). 1 op 2 Antwerpenaren met dieselwagen mag stad niet meer in vanaf 2020. Retrieved from https://www.vab.be/nl/nieuws/2015/5/7/emissiezoneantwerpen, access date 24/5/2016.

Van Goeverden, C., Rietveld, P., Koelemeijer, J., \& Peeters, P. (2006). Subsidies in Public Transport. European Transport $\backslash$ Trasporti Europei, (32), 381-404.

Vanoutrive, T., Van Malderen, L., Jourquin, B., Thomas, I., Verhetsel, A., \& Witlox, F. (2010). Mobility management measures by employers: overview and exploratory analysis for Belgium. European Journal of Transport and Infrastructure Research, 10(2), 121-141.

Verhetsel, A., Thomas, I., Van Hecke, E., \& Beelen, M. (2007). Pendel in België. Deel I: De Woon-Werkverplaatsingen. Brussels: Statistics Belgium.

Verhetsel, A., Vanoutrive, T., \& Zijlstra, T. (2014). Het woon-werkverkeer in Vlaanderen: zoektocht naar indicatoren. Antwerp: Policy Research Centre on Commodity and Passenger Flows (MOBILO).

Witlox, F., Derudder, B., \& Van Acker, V. (2013). Transport geography in Belgium. Journal of Transport Geography, 29, 108-110.

Zijlstra, T., Vanoutrive, T., \& Verhetsel, A. (2014). Het Mobiliteitsbudget: Een Verkenning. Policy Research Centre on Commodity and Passenger Flows (MOBILO).

Zijlstra, T., Vanoutrive, T., \& Verhetsel, A. (2015). A meta-analysis of the effectiveness of park-and-ride facilities. European Journal of Transport and Infrastructure Research, 15(4), 597-612. 